\title{
PEMBANGUNAN APLIKASI MANAJEMEN TUGAS MAHASISWA BERBASIS MOBILE ANDROID
}

\author{
Zulafwan, Wahyu Joni Kurniawan, Pandu Pratama Putra \\ Jurusan Teknik Informatika STMIK Amik Riau \\ Jl. Purwodadi Indah KM.10, Kec Tampan, Pekanbaru,Riau \\ zulafwan@stmik-amik-riau.ac.id, wahyujonikurniawan@stmik-amik-riau.ac.id, \\ pandupratamaputra@stmik-amik-riau.ac.id
}

\begin{abstract}
The task of the student is one of the assessment of student learning outcomes, the students who do not collect the task due to forgetting or not knowing the duty of the lecturer is very detrimental to the students. The tasks collected with the softcopy type sometimes troubled the students in collecting and also making it difficult for the lecturers to make all student assignments. By utilizing technology in supporting the lectures, mobile applications that are built to help students and lecturers in the lecture. Applications are built consisting of two sides, the first web application that will be used lecturers concerned in managing student tasks. Second, mobile-based applications that will be paired to student mobile devices that will interact with lecturers.
\end{abstract}

Keywords : Client-server, Android, Task Management

\begin{abstract}
Abstrak
Tugas mahasiswa merupakan salah satu penilaian hasil belajar mahasiswa, adanya mahasiswa yang tidak mangumpulkan tugas dikarenakan lupa ataupun tidak mengetahui adanya tugas dari dosen sangat merugikan mahasiswa. Tugas yang dikumpul dengan jenis softcopy terkadang menyusahkan mahasiswa dalam mengumpulkan dan juga menyulitkan dosen dalam mengupulkan semua tugas mahasiswa. Dengan memanfaatkan teknologi dalam penunjang perkuliahan, aplikasi mobile yang dibangun sangat membantu mahasiswa maupun dosen dalam perkuliahan. Aplikasi yang dibangun terdiri dari dua sisi, pertama aplikasi web yang nantinya akan digunakan dosen yang bersangkutan dalam memanajemen tugas mahasiswa. Kedua, aplikasi berbasis mobile yang akan dipasangkan ke perangkat mobile mahasiswa yang akan berinteraksi dengan dosen.
\end{abstract}

Kata Kunci : Client-server, Android, Manajemen Tugas

\section{PENDAHULUAN}

Masalah yang umum terjadi hampir disetiap waktu pengumpulan tugas adalah adanya beberapa mahasiswa yang terlambat dalam pengumpulan tugas, ataupun mahasiswa yang tidak tahu akan adanya tugas yang diberikan oleh dosen karena tidak hadir ketika dosen memberikan tugas, atau tidak ada 
koordinasi antar mahasiswa dalam kelas. Selain itu adanya beberapa mahasiswa yang mengambil matakuliah ke semester selanjutnya atau mengulang matakuliah disemester sebelumnya sehingga komunikasi terhadap teman sekelasnya kurang terjalin dengan baik. Masalah lain adalah dosen harus mengumpulkan dan menginputkan data nilai tugas mahasiswa sebagai penilaian yang nantinya akan diberikan ke pihak akademis. Dengan jumlah mahasiswa yang banyak dan jumlah tugas yang akan dinilai cukup banyak, maka terkadang dosen mengalami kesulitan dalam melakukan rekap nilai mahasiswa.

Tugas mahasiswa ada yang berupa softcopy yang dikumpul ke dosen melalui email, CD ataupun copy langsung ke komputer dosen. Hal ini kurang efektif karena dosen harus melakukan pengecekan email, mengkopi dari CD ataupun mengkopi dari flashdisk mahasiswa yang rawan akan virus. Harus ada sistem dimana tugas berupa softcopy diupload oleh mahasiswa melalui perangkat mobile atau dengan menmfoto tugasnya sebagai bukti bahwa sudah mengerjakan tugas.Dosen cukup melakukan pengecekan melalui website sehingga mengetahui siapa saja yang sudah mengerjakan tugas dan memberikan penilaian langsung melalui aplikasi.Dosen bisa memberikan penilaian kepada mahasiswa yang cepat dalam mengerjakan tugas dengan melihat waktu memasukkan tugas sehingga menjadi nilai tambah bagi mahasiswa.Dosen juga bisa berinterksi dengan mahasiswa dengan menggunakan aplikasi jika ada mahasiswa yang memang belum mengerjakan tugas.Selain itu aplikasi juga bisa diberikan fitur pengingat jika mahasiswa lupa mengerjakan tugas.

Dalam implementasinya aplikasi web hanya bisa diakses oleh dosen pada perangkat komputernya. Sedangkan aplikasi pada mahasiswa berupa aplikasi android yang akan diinstall pada perangkat mobile masing-masing. Kedua aplikasi tersebut akan saling terhubung. Dosen memberikan instruksi mengenai tugas melalui aplikasi web yang nantinya dikirim ke masingmasing perangkat mahasiswa dan akan ada pemberitahuan dari aplikasi bahwa ada tugas. Mahasiswa yang sudah mengerjakan tugas bisa langsung mengeirimkan tugas berupa softcopy ataupun hasil foto tugas ke aplikasi dosen sehingga dosen mengetahui siapa saja mahasiswa yang telah mengerjakan tugas. Dalam aplikasi mahasiswa akan diberikan alaram sebagai pengingat jika ada mahasiswa belum mengerjakan tugas sebelum waktu pengumpulan. Tujuan akhir dari penelitian ini adalah membangun sebuah aplikasi yang dapat digunakan oleh dosen dalam memberikan dan mengumpulkan tugas mahasiswa.Sehingga tidak ditemukan lagi masalah keterlambatan pengumpulan tugas dengan alasan apapun seperti tidak mengetahui informasi adanya tugas jika mahasiswa tidak hadir dalam perkuliahan. 


\section{METODOLOGI PENELITIAN}

\subsection{Client-Server}

Client merupakan terminal yang digunakan oleh pengguna untuk meminta layanan tertentu yang dibutuhkan.Terminal client dapat berupa $P C$, ponsel, komunikator, robot, televisi, dan peralatan lain yang membutuhkan informasi. Server merupakan pihak yang menyediakan layanan. Server dapat berupa basis data SQL, Monitor TP, servergroupware, server objek, atau Web. Client-Server adalah pembagian kerja antara server dan client yang mengakses server dalam suatu jaringan. Arsitektur client-server adalah desain dimana sebuah aplikasi terdiri dari client dan server yang saling berkomunikasi ketika mengakses server dalam suatu jaringan [1].

\subsection{Android}

Android adalah sebuah sistem operasi pada handphone yang bersifat terbuka dan berbasis pada sistem operasi Linux.Android bisa digunakan oleh setiap orang yang ingin menggunakannya pada perangkat mereka. Android menyediakan platform terbuka bagi para pengembang untuk menciptakan aplikasi mereka sendiri yang akan digunakan untuk bermacam peranti bergerak [2].

\subsection{PHP}

PHP adalah bahasa pemrograman script server-side yang didesain untuk pengembangan web.Selain itu, PHP juga bisa digunakan sebagai bahasa pemrograman umum.PHP di kembangkan pada tahun 1995 oleh Rasmus Lerdorf, dan sekarang dikelola oleh The PHP Group.Situs resmi PHP beralamat di http://www.php.net [3].

\subsection{UML}

Unified Modeling Language adalah salah satu standar bahasayang banyak digunakan di dunia industri untuk mendefinisikan requirement, membuat analisa dan desain, serta menggambarkan arsitektur dalam pemrograman berorientasi objek[4-9].

\section{HASIL DAN PEMBAHASAN}

\subsection{Identifikasi Masalah}

Tugas mahasiswa yang akan dikumpul ada yang berupa softcopy yang dikumpul ke dosen melalui email, CD ataupun copy langsung ke leptop dosen. Hal ini kurang efektif karena dosen harus melakukan pengecekan email, mengkopi dari CD ataupun mengkopi dari flashdisk mahasiswa yang rawan akan virus. Masalah lain yang biasanya terjadi adalah mahasiswa lupa bahwa adanya tugas yang diberikan oleh dosen, selain itu pengiriman tugas melalui email dirasakan merepotkan. Harus ada sistem dimana tugas berupa softcopy diupload oleh mahasiswa melalui perangkat mobile atau dengan mengcapture tugasnya sebagai bukti bahwa sudah mengerjakan tugas. Dosen cukup 
melakukan pengecekan melalui website sehingga mengetahui siapa saja yang sudah mengerjakan tugas.

\subsection{Analisis Sistem}

Aplikasi yang dibuat terdiri atas dua bagian.Pertama, sisi server yang terdiri atas pembuatan website administrator dan database.Kedua, sisi client yang merupakan aplikasi berbasis Android.Gambaran sistem aplikasi secara umum dapat dilihat pada gambar 1 .

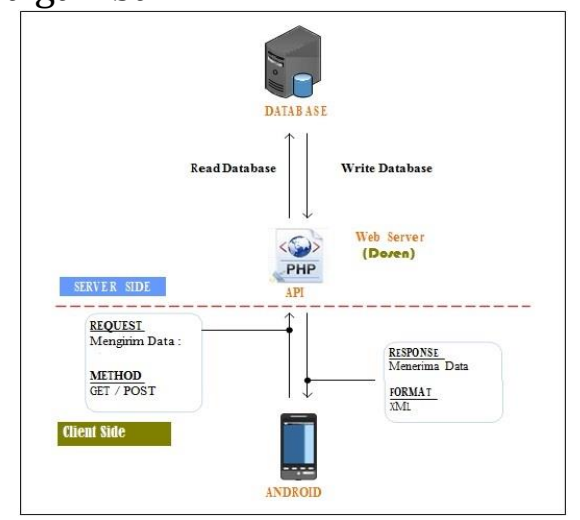

Gambar 1. Perancangan Sistem.

\subsection{Perancangan Sistem}

Perancangan system dilakukan pada dua tipe aplikasi yaitu perancangan untuk aplikasi server yang digunakan oleh dosen menggunakan PHP dan aplikasi client yang dibangun menggunakan android. Sisi client dibangun pada aplikasi mobile dengan sistem operasi android, sedangkan sisi server dibangun dengan basis web.Kedua subsistem ini saling terhubung dan berkomunikasi dengan bantuan web service. Proses komunikasi antara client Android dengan server dapat dilihat pada gambar 2. dibawah ini:

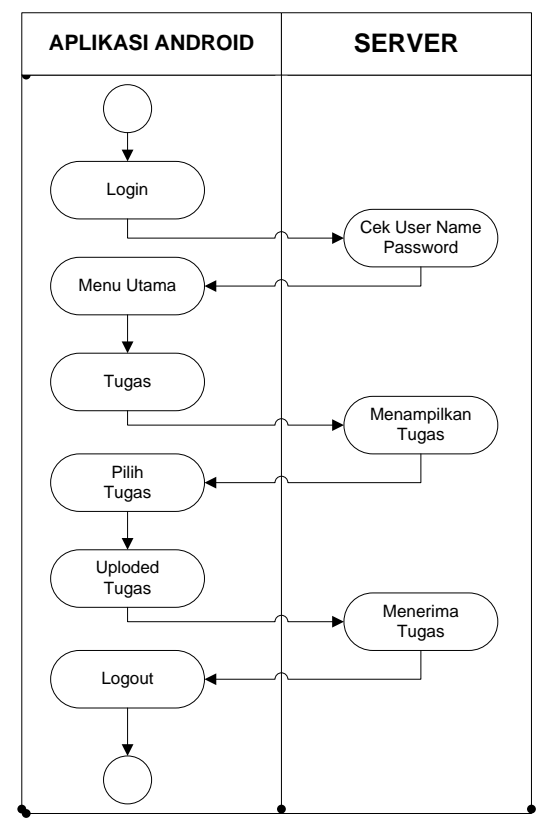

Gambar 2. komunikasi antaraclientAndroid denganserver

Aplikasi Manajemen Tugas Mahasiswa Berbasis Mobile Android (Zulafwan) | 206 


\subsubsection{Berbasis Web}

Setelah analisa sistem selesai, maka tahapan selanjutnya adalah Perancang aplikasi yang dibangun berbasis web. Perancangan aplikasi meliputi pemodelan aplikasi menggunakan unified modeling language(UML) dengan menggunakan beberapa diagram yang menjelaskan bagaimana dan apa saja yang bisa dilakukan User dalam menggunakan aplikasi.

\section{Usecase Diagram Sistem Berbasis Web}

Use case diagram adalah model fungsional sebuah sistem yang menggunakan actor dan use case. Use case adalah layanan atau fungsi-fungsi yang disediakan oleh sistem untuk penggunanya.

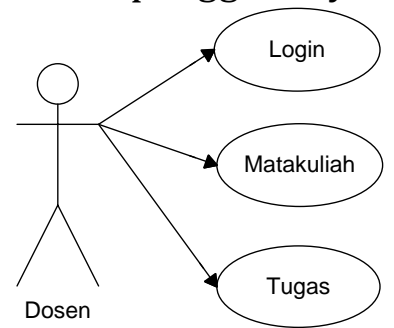

Gambar 3. Usecase Dosen

Pada diagram diatas dapat dilihat dosen bisa melakukan login, lalu mengambil matakuliah dan memberikan tugas.layanan ini dilakukan dosen pada aplikasi web.

\section{Class Diagram Sistem Berbasis Web}

Class diagram digunakan untuk menggambarkan struktur kelas dan objek yang akan digunakan dalam sistem yang akan dibangun, adapun gambar diagram dari class diagram sistem dapat dilihat pada gambar 4 di bawah ini.

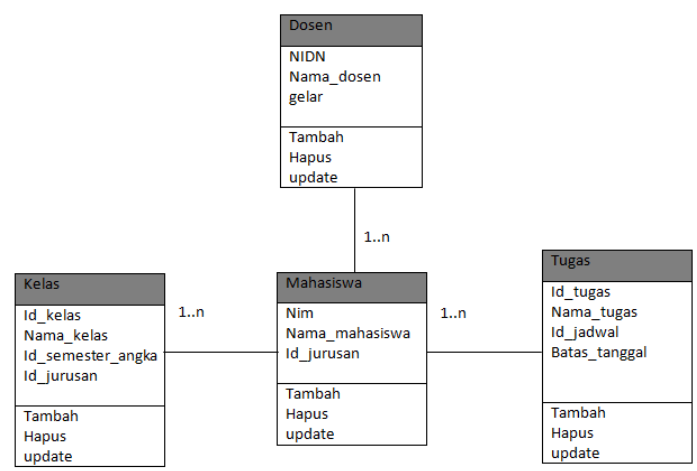

Gambar 4. Class Diagram Sistem Berbasis Web

Pada gambar di atas menggambarkan hubungan antara class untuk membangun sistem dan menjelaskan hubungan antara class .

\section{Activity Diagram Sistem Berbsis Web}

Activity diagram dosen menggambarkan kegiatan apa saja yang bisa dilakukan dosen dalam sistem. Diagram tersebut dapat dilihat pada gambar 5 di bawah ini . 


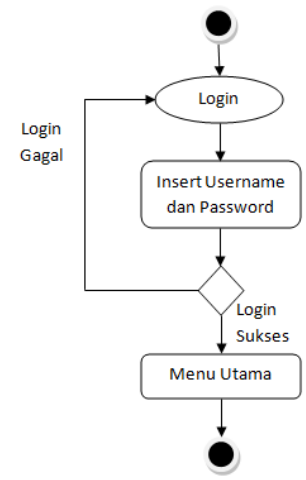

Gambar 5. Activity Diagram Dosen Login

Pada gambar di atas dapat dilihat aktivitas login yang dilakukan dosen dengan memasukkanusername dan password. Jika salah dalam melakukan login, maka dosen harus memasukkan username dan password kembali

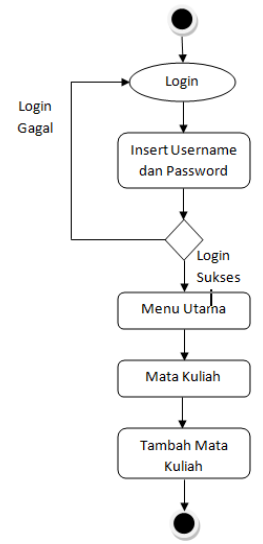

Gambar 6. Activity Diagram Dosen menambah Matakuliah

Pada gambar di atas dapat dilihat aktivitas menambah matakuliah yang dilakukan dosen. Setelah dosen login, maka akan muncul menu utama dan dosen bisa memilih menu matakuliah untuk menambah matakuliah.

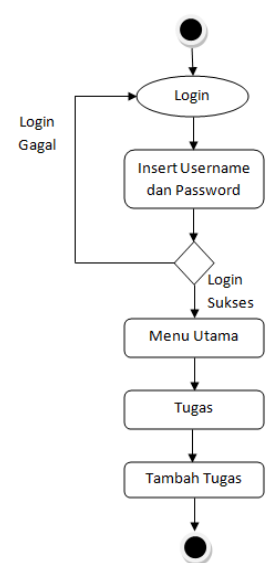

Gambar 7. Activity Diagram Dosen menambah Tugas

Aplikasi Manajemen Tugas Mahasiswa Berbasis Mobile Android (Zulafwan) | 208 
Pada gambar di atas dapat dilihat aktivitas menambah tugas yang dilakukan dosen. Setelah dosen login, maka akan muncul menu utama dan dosen bisa memilih menu tugas untuk menambah tugas.

\section{Deployment Diagram Sistem Berbasis Web}

Deployment diagram menggambarkan bagaimana komponen di deploy dalam infrastruktur system, dimana komponen akan terletak, bagaimana kemampuan jaringan pada lokasi tersebut, spesifikasi server, dan hal-hal lain yang bersifat fisikal. Berikut adalah gambar diagram deployment system ini.

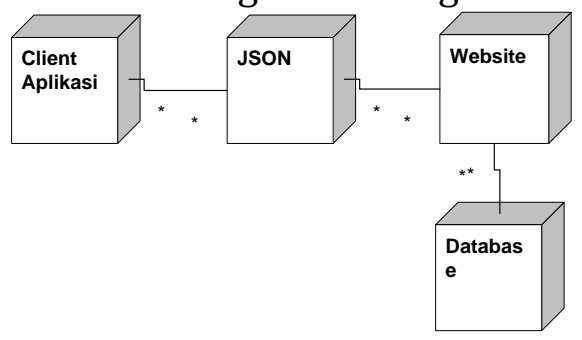

\section{Gambar 8. Deployment Diagram Sistem Berbasis Web}

Pada gambar 8. dapat dilihat komponen deploy dari sistem ada 4 yaitu client aplikasi sebagai aplikasi mahasiswa, JSON sebagai penghubung website dan client aplikasi, website sebagai server dan antarmuka dosen, lalu database sebagai penyimpanan.

\subsubsection{Berbasis Android}

Setelah analisa sistem selesai, maka tahapan selanjutnya adalah Perancang aplikasi yang dibangun berbasis android. Perancangan aplikasi meliputi pemodelan aplikasi menggunakan unified modeling language(UML) dengan menggunakan beberapa diagram yang menjelaskan bagaimana dan apa saja yang bisa dilakukan User dalam menggunakan aplikasi.

\section{Usecase Diagram Sistem Berbasis Android}

Use case diagram adalah model fungsional sebuah sistem yang menggunakan actor dan use case. Use case adalah layanan atau fungsi-fungsi yang disediakan oleh sistem untuk penggunanya.

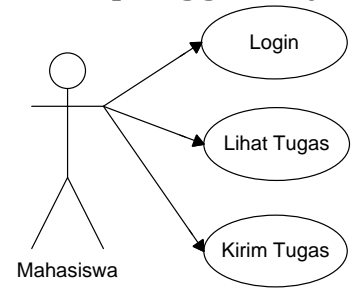

\section{Gambar 9. Usecase Mahasiswa}

Pada diagram diatas dapat dilihat mahasiswa bisa melakukan login, lalu melihat tugas dan mengirim tugas, layanan ini dilakukan dosen pada aplikasi web.

\section{Class Diagram Sistem Berbasis Android}

Class diagram digunakan untuk menggambarkan struktur kelas dan objek yang akan digunakan dalam sistem yang akan dibangun, adapun 
gambar diagram dari class diagram sistem dapat dilihat pada gambar $10 \mathrm{di}$ bawah ini.

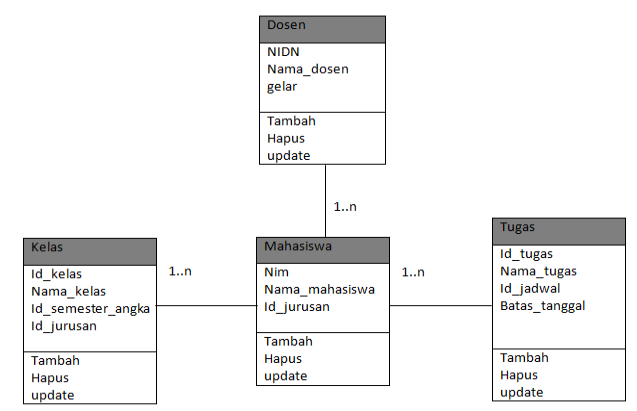

\section{Gambar 10. Class Diagram Sistem Berbasis Android}

Pada gambar di atas menggambarkan hubungan antara class untuk membangun sistem dan menjelaskan hubungan antara class .

\section{Activity Diagram Sistem Berbsis Android}

Activity diagram mahasiswa menggambarkan kegiatan apa saja yang bisa dilakukan mahasiswa dalam sistem. Diagram tersebut dapat dilihat pada gambar 11 di bawah ini .

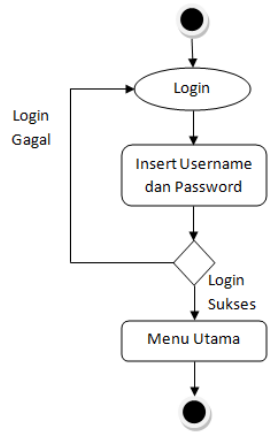

\section{Gambar 11 Activity Diagram Mahasiswa Login}

Pada gambar di atas dapat dilihat aktivitas login yang dilakukan mahasiswa dengan memasukkan username dan password.jika salah dalam melakukan login, maka mahasiswa harus memasukkan username dan password kembali

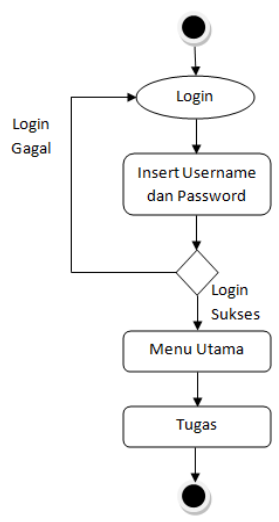

Gambar 12. Activity Diagram Mahasiswa lihat tugas 
Pada gambar di atas dapat dilihat aktivitas melihat tugas yang dilakukan mahasiswa. Setelah mahasiswa login, maka akan muncul menu utama dan mahasiswa bisa memilih menu tugas untuk melihat tugas.

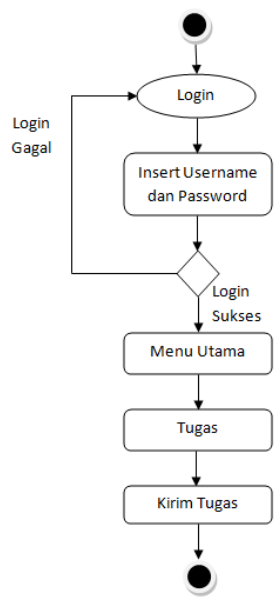

\section{Gambar 13. Activity Diagram Mahasiswa mengirim tugas}

Pada gambar di atas dapat dilihat aktivitas mengirim tugas yang dilakukan mahasiswa. Setelah mahasiswa meilihat, maka akan muncul menu untuk mengirim tugas yang diberika oleh dosen.

\section{Deployment Diagram Sistem Berbasis Android}

Deployment diagram menggambarkan bagaimana komponen di deploy dalam infrastruktur system, dimana komponen akan terletak, bagaimana kemampuan jaringan pada lokasi tersebut, spesifikasi server, dan hal-hal lain yang bersifat fisikal.Berikut adalah gambar diagram deployment system ini.

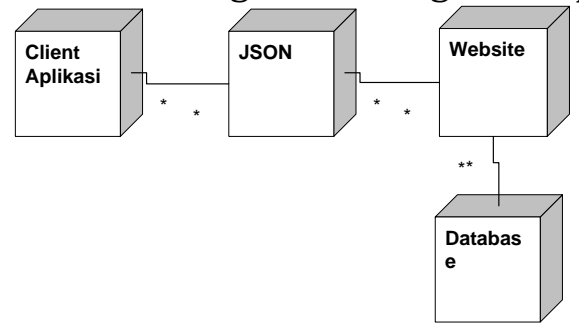

\section{Gambar 14. Deployment Diagram Sistem Berbasis Android}

Pada gambar 14 dapat dilihat komponen deploy dari sistem ada 4 yaitu client aplikasi sebagai aplikasi mahasiswa, JSON sebagai penghubung website dan client aplikasi, website sebagai server dan antarmuka dosen, lalu database sebagai penyimpanan.

\section{DesainTampilan}

Client Android terdiri atas banyak activity. Activity tersebut saling berhubungan antara satu denganlainnya. gambaran dari desain aplikasi android dapat dijelaskan pada gambar 15. 


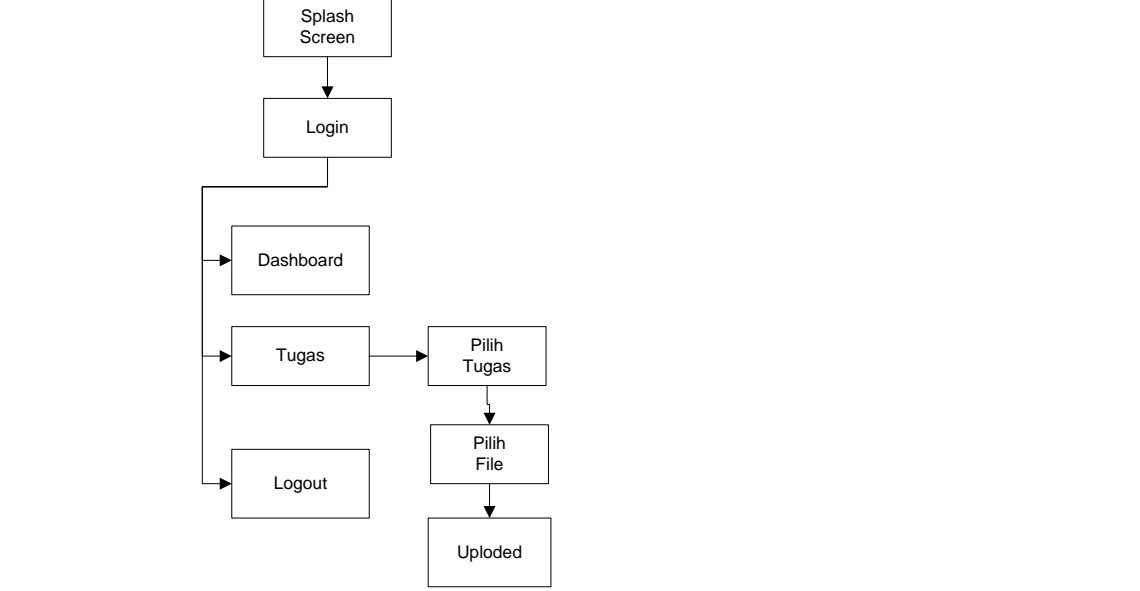

Gambar 15. Desain Client Android

\subsubsection{Pengujian Sistem}

\section{Website Manajemen Tugas Mahasiswa}

Aplikasi yang dijalankan pertama adalah aplikasi pada sis server yaitu aplikasi web dengan nama manajementugas yang juga merupakan domain dari website tersebut.untuk melakukan percobaan dapat diakses dengan menggunakan localhost dengan akses http://localhost/Manajemen_MHS lalu akan muncul halama login dari website, untuk username dan password didapat dari database MySql.

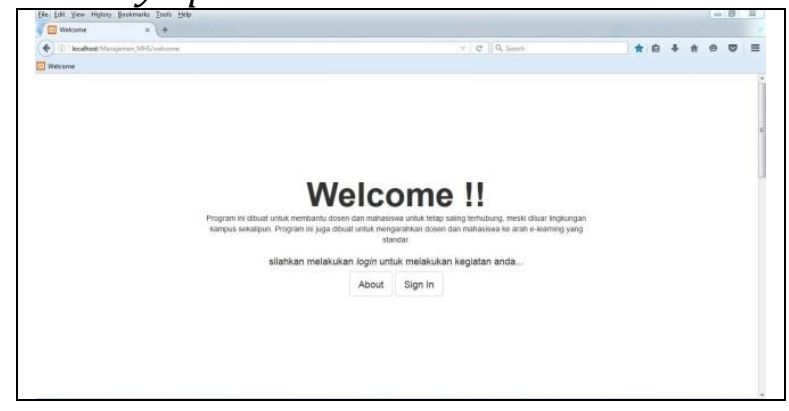

Gambar 16. Tampilan Halaman Welcome

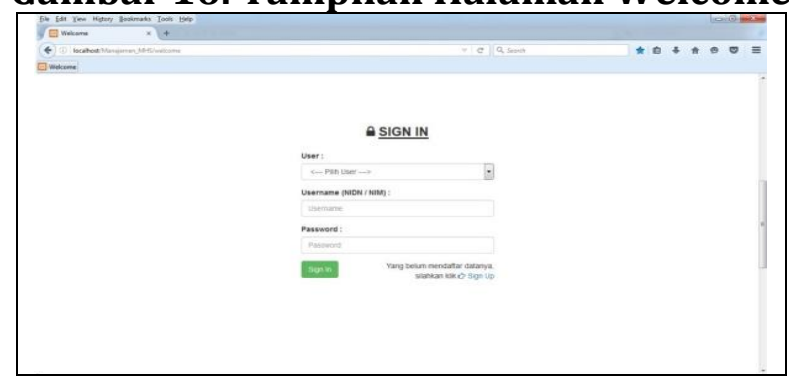

Gambar 17. Tampilan Login

Setelah dosen sukses login dengan menggunakan username dan password maka akan muncul menu utama dari website tersebut terdapat 2 menu utama yaitu menu daftar mengajar dan menu tugas. 


\section{Gambar 18. Tampilan Menu Utama}

\section{Aplikasi Android Manajemen Tugas}

Pada aplikasi disisi client yang digunakan oleh mahasiswa, dibangun menggunakan bahasa pemograman android, dimana aplikasi ini dapat menampilkan data pada database MySql dan mengirimkan data ke database yang nantinya akan dilihat dan dicek oleh dosen menggunakan aplikasi web nya.berikut tampilan aplikasi android manajemen tugas mahasiswa.ketika aplikasi dibuka akan tampil splashscreen dan dilanjutkan dengan halaman login.

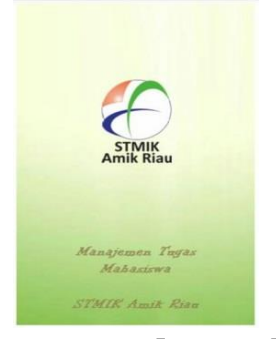

\section{Gambar 19. Tampilan Splashscreen}

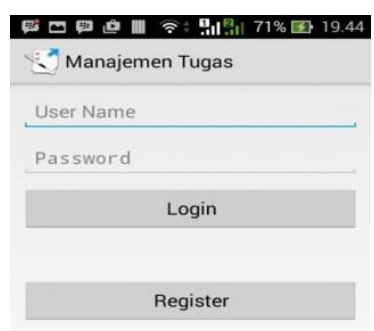

Gambar 20. Tampilan Login

Setelah mahasiswa login dengan benar maka akan muncul halaman utama dari aplikasi.terdapat menu tugas.dalam menu ini mahasiswa dapat melihat tugas yang dikirimkan oleh dosen beserta batas pengumpulan. pada menu ini juga mahasiswa bias mengirimkan file ataupun mencapture tugas yang sudah dikerjakan.berikut tampilan menu utama dari aplikasi :

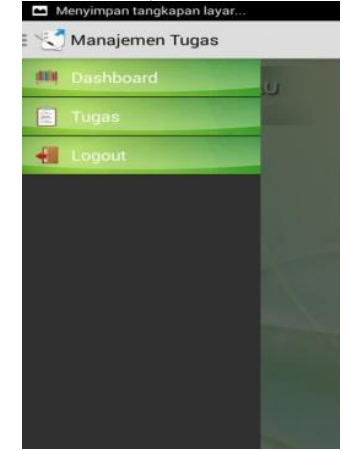

Gambar 21. Tampilan Menu Utama

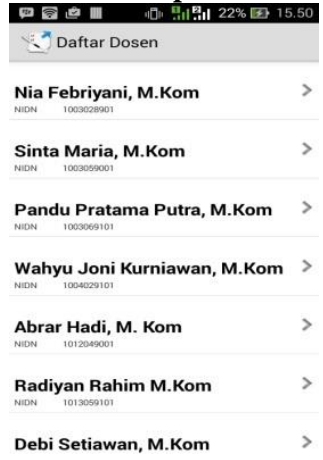

Gambar 22 Tampilan Daftar Dosen 
http://tunasbangsa.ac.id/ejurnal/index.php/jsakti

\section{Gambar 23. Tampilan Lihat Tugas}

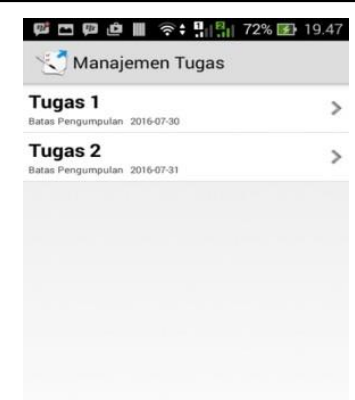

\section{Gambar 24. Tampilan daftar tugas}

\section{SIMPULAN}

Dengan memanfaatkan teknologi dalam penunjang perkuliahan, Pembangunan Aplikasi Manajemen Tugas Mahasiswa Berbasis Mobile Android yang dibangun sangat membantu mahasiswa maupun dosen dalam perkuliahan. Aplikasi yang dibangun terdiri dari dua sisi, pertama aplikasi $w e b$ yang nantinya akan digunakan dosen yang bersangkutan dalam memanajemen tugas mahasiswa. Kedua, aplikasi berbasis mobile yang akan dipasangkan ke perangkat mobile mahasiswa yang akan berinteraksi dengan dosen.

\section{DAFTAR PUSTAKA}

[1] Irsan, M., Studi, P., Informatika, T., Teknik, F., Tanjungpura, U., \& Prof, J. (2015). RANCANG BANGUN APLIKASI MOBILE NOTIFIKASI BERBASIS ANDROID UNTUK MENDUKUNG KINERJA DI INSTANSI PEMERINTAHAN. Universitas Tanjungpura.

[2] Ma, L., Gu, L., \& Wang, J. (2014). Research and Development of Mobile Application for Android Platform. International Journal of Multimedia and Ubiquitous Engineering, 9(4), 187-198.

[3] Sabrina, Y. (2015). RANCANG BANGUN APLIKASI PEMBELAJARAN BAHASA KIASAN ( MAJAS ) BAHASA INDONESIA BERBASIS ANDROID. STMIK GI MDP, 1-9.

[4] http://www.duniailkom.com/pengertian-dan-fungsi-php-dalampemograman-web/

[5] https://id.wikipedia.org/wiki/XAMPP, Diakses tanggal 20 juni 2016

[6] http://Wikipedia.org MySql Database, Diakses tanggal 20 juni 2016

[7] https://developer.android.com/guide/index.html, Diakses tanggal 7 mei 2016

[8] http://www.json.org/json-id.html, Diakses tanggal 20 juni 2016

[9] http://www.instructionaldesign.org/models/addie.html, Diakses tanggal 20 juni 2016 